\title{
Impact of Biochar on Earthworm Populations: A Review
}

\author{
Sharon L. Weyers ${ }^{1}$ and Kurt A. Spokas ${ }^{2}$ \\ ${ }^{1}$ USDA Agricultural Research Service, North Central Soil Conservation Research Lab, 803 Iowa Avenue, Morris, MN 56267, USA \\ ${ }^{2}$ USDA Agricultural Research Service, Soil and Water Management Unit, University of Minnesota, 1991 Upper Buford Circle, \\ S. Paul, MN 55108, USA \\ Correspondence should be addressed to Sharon L. Weyers, sharon.weyers@ars.usda.gov
}

Received 2 June 2011; Accepted 18 August 2011

Academic Editor: Alessandro Piccolo

Copyright (๑) 2011 S. L. Weyers and K. A. Spokas. This is an open access article distributed under the Creative Commons Attribution License, which permits unrestricted use, distribution, and reproduction in any medium, provided the original work is properly cited.

\begin{abstract}
Despite the overwhelming importance of earthworm activity in the soil system, there are a limited number of studies that have examined the impact resulting from biochar addition to soil. Biochar is part of the black carbon continuum of chemothermal converted biomass. This review summarizes existing data pertaining to earthworms where biochar and other black carbon substances, including slash-and-burn charcoals and wood ash, have been applied. After analyzing existing studies on black carbon, we identified that these additions have a range from short-term negative impacts to long-term null effects on earthworm population density and total biomass. Documented cases of mortality were found with certain biochar-soil combinations; the cause is not fully understood, but hypothesized to be related to $\mathrm{pH}$, whether the black carbon is premoistened, affects feeding behaviors, or other unknown factors. With wood ashes, negative impacts were overcome with addition of other carbon substrates. Given that field data is limited, soils amended with biochar did not appear to cause significant long-term impacts. However, this may indicate that the magnitude of short-term negative impacts on earthworm populations can be reduced with time.
\end{abstract}

\section{Introduction}

The importance of earthworms in soil genesis (i.e., bioturbation) has long been recognized and dates back to the 1800 's with some of the initial work by Charles Darwin [1]. In his seminal publication, Darwin [2] noted that earthworm burrowing and casting activity together were the primary force in mixing soil layers and burying surface debris. Through this bioturbation, earthworms increase soil porosity affecting soil aeration as well as water infiltration. Earthworm casts are also important protective and dispersal vehicles for soil microbes and nutrients. Taken altogether, earthworms have been recognized as ecosystem engineers, or organisms that can have a profound influence on the structure and functioning of soils [3]. By way of function, earthworms have profound direct and indirect impacts on the availability of nutrients, particularly through increased decomposition of plant residues and turnover of soil organic matter. Thus, what positively or negatively affects soil biota [4] may indirectly affect soil function and plant growth.
The functioning of intensively managed soil systems has increasingly become dependent on external inputs to maintain high levels of productivity. Management practices which degrade soil organic matter, including heavy tillage, degrade a soil's inherent quality and reduce fertility [5, 6]. For soil quality improvement, recommendations call for organic inputs of animal manures, green manures and cover crops to replace lost carbon, and reduction of tillage to prevent soil loss and/or rapid $\mathrm{C}$ turnover [7, 8]. Longstanding evidence points to the positive increases in earthworm populations when amending soils with organic inputs. Along these same lines, increased plant productivity [9] is frequently cited, but with high abundance of large surface-continuous macropores associated with deep burrowing species [10] increased loss of nutrients through infiltration could occur [11].

In a new drive to improve soil fertility and increase $\mathrm{C}$ sequestration, recommendations to amend soil with biochar, which is black carbon, are surfacing around the globe. However, recent evidence has indicated that some biochars 
may have negative effects on the soil biota, in particular earthworms [12]. Potential mortality aside, earthworms may interact with biochar amendments to increase macro- and micronutrient availability, in positive (e.g., increased plant productivity; [13]) or potentially detrimental ways (e.g., increased leaching of heavy metals; [14]). The availability of information to determine what likely will happen to earthworm populations, nutrient cycling, and overall soil function with land application of biochar is limited. The purpose of this review is to evaluate the existing data on earthworm effects from biochar application. We will define biochar and delineate the direct and indirect impacts of biochar and like substances on earthworms, including Enchytraeidae, and their associated soil functions. We will identify knowledge gaps and provide recommendations for future research directions.

\section{What Is Biochar?}

The terms and definitions applied to black carbon and "biochar" are dynamic [15]. In its current application, biochar is the solid residual remaining after biomass pyrolysis, which is produced as a vehicle of atmospheric carbon sequestration $[16,17]$. Biochar spans the entire continuum of black carbon residual thermochemical conversion products [18]. The International Biochar Initiative extends this definition to describe the enhanced black earths, or Terra preta soils, formed by historical inputs of pyrolyzed agricultural waste or other organic material turned into a soil enhancing amendment and currently shown "to improve soil functions and to reduce emissions" of greenhouse gases [19]. However, it is important to realize that the unique aspect of biochar is rooted in the carbon sequestration potential.

Research relevant to biochar encompasses studies on black carbon which includes black earths, wildfire charcoals, chars, and wood ash. For instance, numerous studies have examined the potential impacts of biochar amendments on soil fertility [20-23] and greenhouse gas production [24-29]. Evaluation of biochar stability $[18,30]$ and economic/life cycle analyses [31-35] has also been performed. These studies and others evaluating potential implications of biochar which are not pertinent to earthworms are reviewed elsewhere [4, 36-39]. In evaluating these biochar studies caution does have to be applied as the method of production, that is, temperature and oxygen conditions, in addition to the feedstock will affect the chemical and physical properties of the biochar produced [18] and likely their impact on the soil environment. Thus, allowing for biochar customization for a particular soil improvement need [40].

\section{Lab and Field Studies on Biochar}

The majority of studies on biochar, and related materials, conducted over the last few decades have been laboratory assays. The converted feedstocks evaluated ranged from crop residues to manures, to hardwood and softwood materials. The conversion products can be placed into three categories: charcoals resulting from slash-and-burn; synthetic biochar

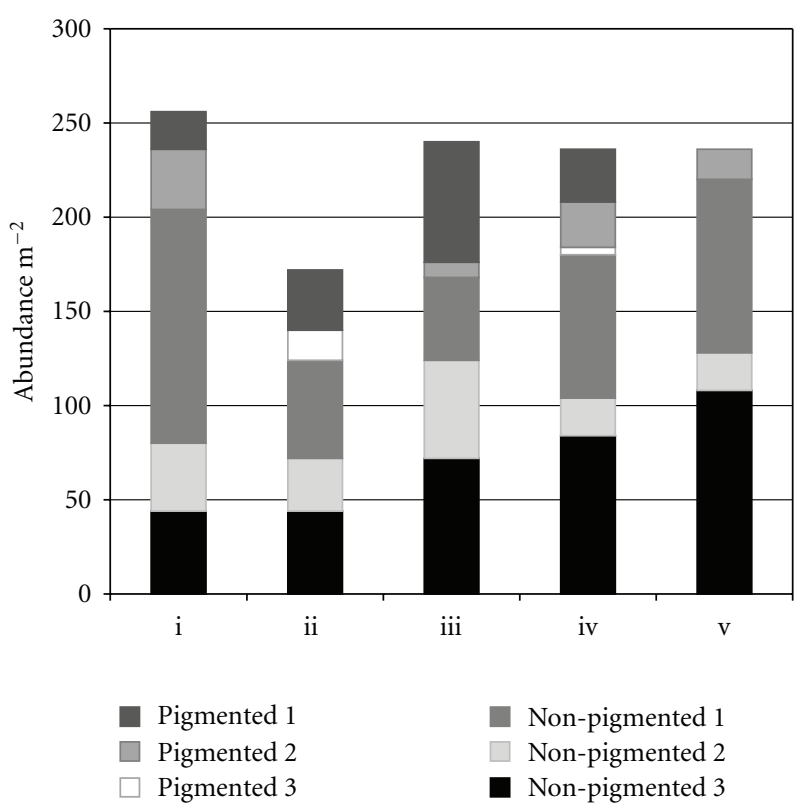

FIGURE 1: Abundance of earthworms by pigmentation and size class, in biochar plots sampled at Rosemount, $\mathrm{MN}$; treatments are (i) control (no amendment), (ii) composted manure; (iii) fast pyrolysis hardwood biochar, (iv) fast pyrolysis hardwood biochar + manure, (v) fast pyrolysis macadamia nut biochar. See text for description of size class.

produced for industrial purposes; and wood ash. Though less clearly related to biochar, wood ash, which has a lower carbon content than biochar, is analogous to biochar amendments because of similarity in the liming impact, soil fertility, and soil moisture content alterations [41-43]. Various direct impacts on earthworm behavior, growth, survivorship, population dynamics, and cell damage have been observed. These impacts along with characteristics of the material tested, study location, soil type and $\mathrm{pH}$, and earthworm species are summarized in Table 1. As few field studies were available, we present new data on field populations of earthworms potentially impacted by application of synthetic biochars (Figure 1; see Section 3.4.1).

3.1. Slash-and-Burn Char. Slash-and-burn practices are often used to prepare forested land or fallow land with existing crop residues for subsequent crop production. Charcoal additions along with slash-and-burn practices paved the way for the formation of carbon-dense fertile black soils [44] (see Section 3.4). Under this premise, Topoliantz and Ponge $[45,46]$ undertook the evaluation of an earthworm's reaction to charcoal obtained from a slash-and-burn field in laboratory analyses. In these two studies, a geophagous tropical peregrine earthworm, Pontoscolex corethrurus, was presented with pure soil (Oxisol), pure charcoal, or $60 \%$ sieved $(<2 \mathrm{~mm})$ wood-derived charcoal-soil mixtures, and growth rates, ingestion, burrowing, and casting activity were evaluated. The exact pyrolysis conditions producing the charcoal are not known. However, neither study indicated any pronounced effect on earthworm survivorship or growth 

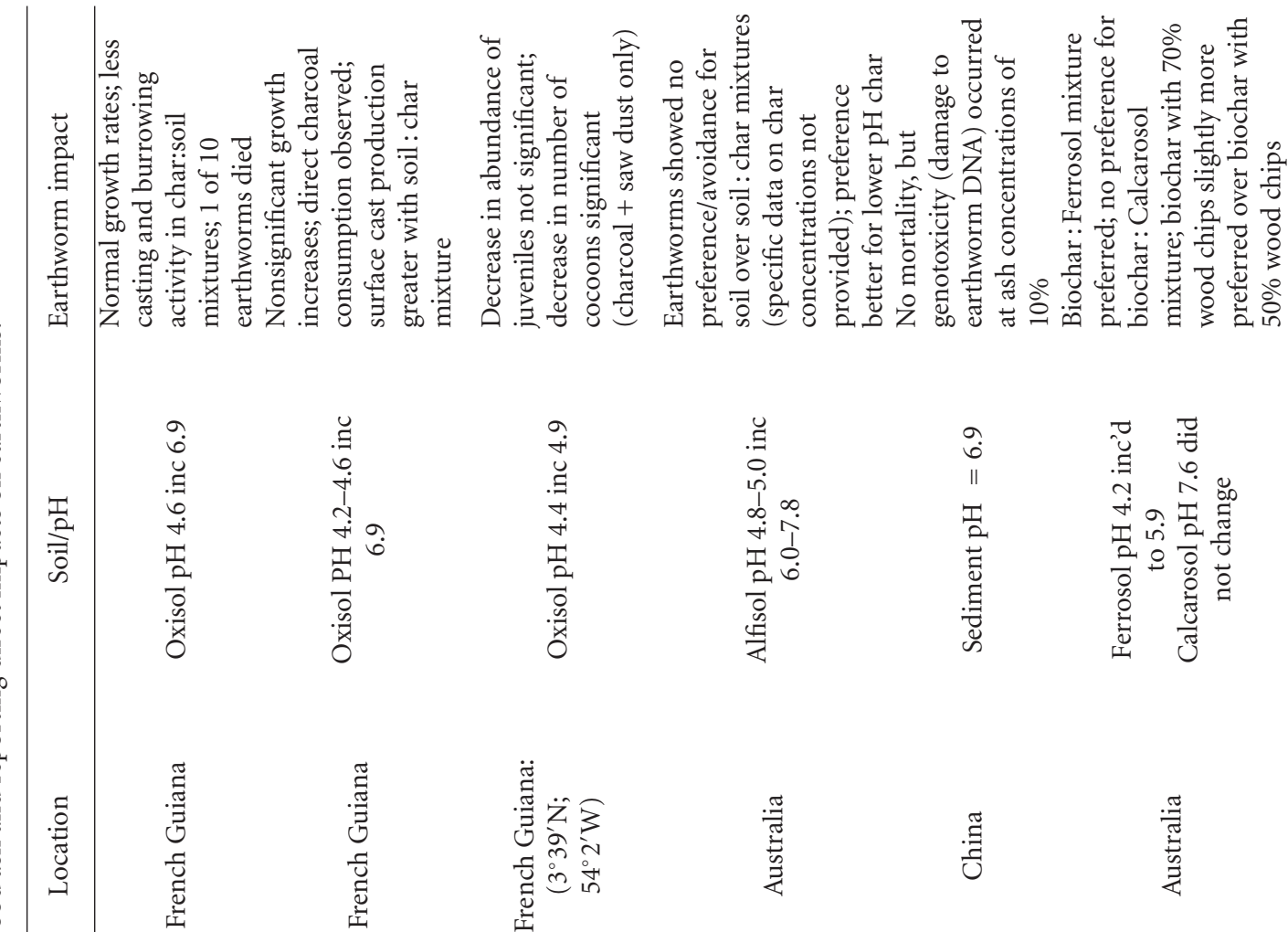

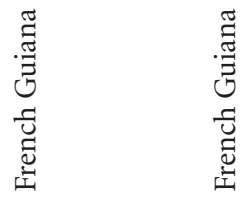
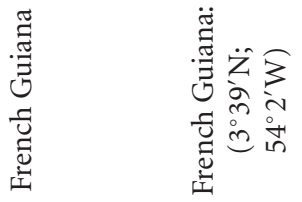

㵡

苞

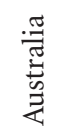

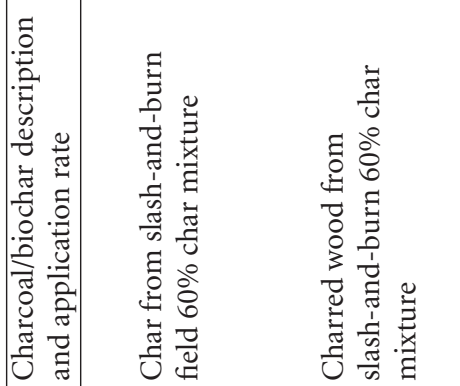

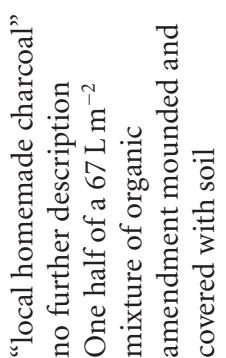

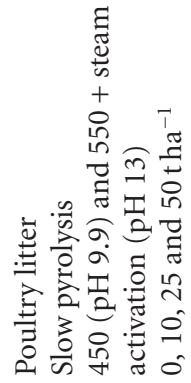
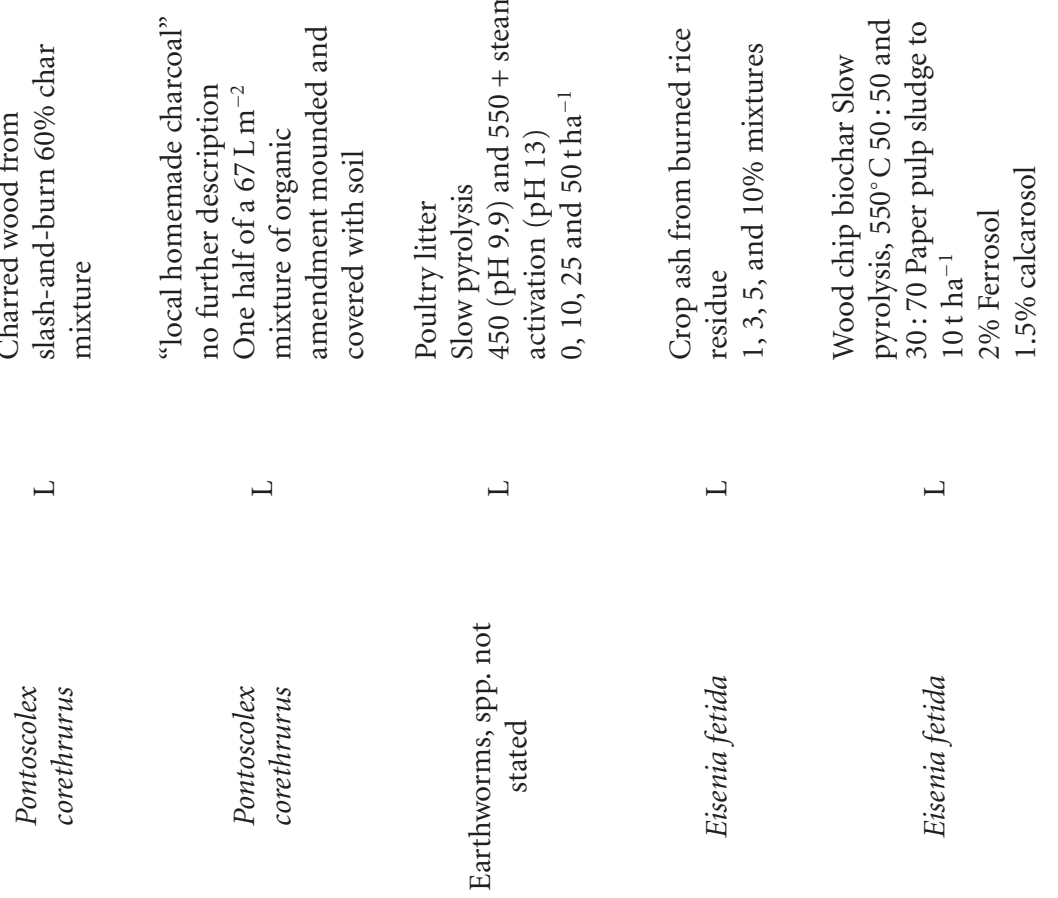

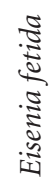

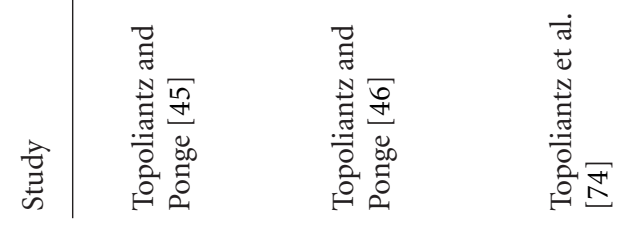

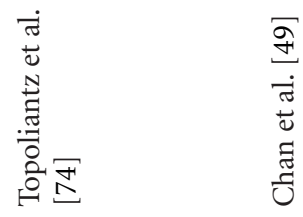

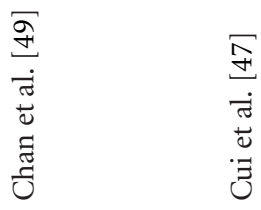

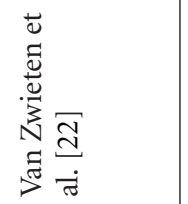




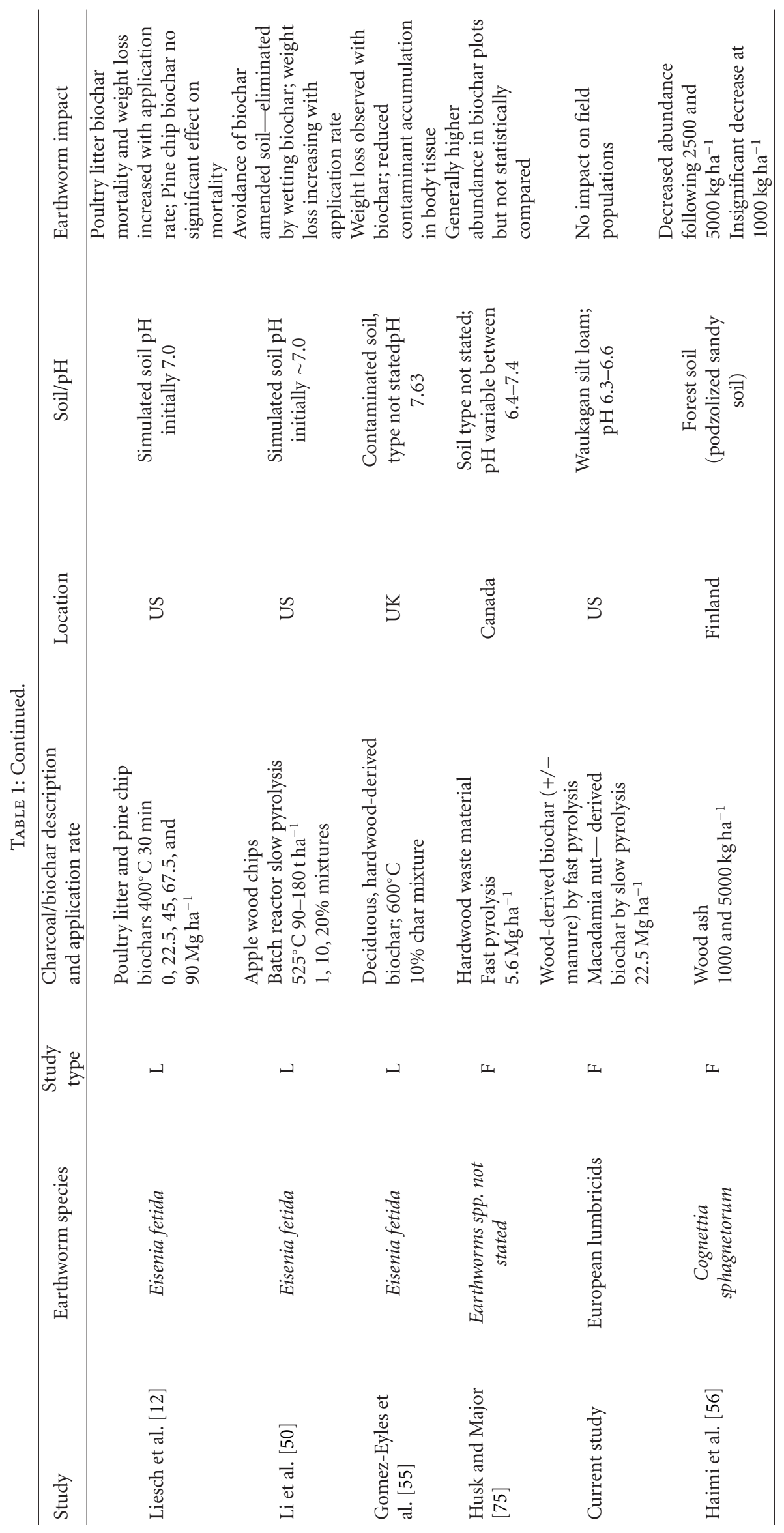




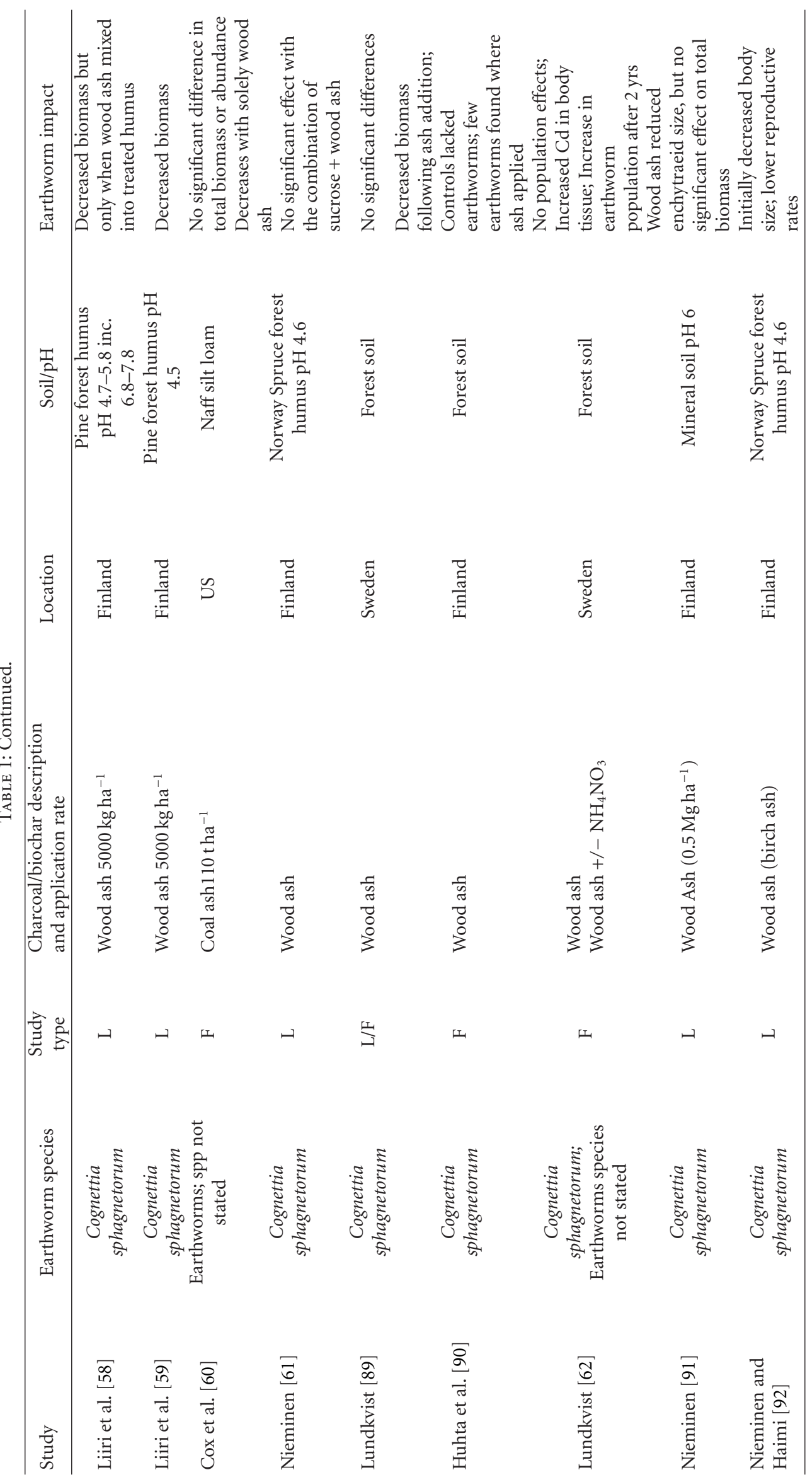


rates (Table 1). The presence of charcoal did affect earthworm activity, as discussed in Section 4. One noted impact of the charcoal application was the increase in soil $\mathrm{pH}$ from moderately acidic to nearly neutral $\mathrm{pH}$ values (Table 1 ). The neutralizing of soil $\mathrm{pH}$ was provided as a reason why earthworms were not deterred from burrowing into the charcoal-soil mixtures [46].

The prospect of using char from slash-and-burn management practices in rice crops in China for reducing environmental contaminants was evaluated [47]. Rice crop residue was charred in the laboratory to mimic field slashand-burn residue and mixed into sediment of $4.7 \% \mathrm{C}$ and a $\mathrm{pH}$ of 6.9. Addition of the rice char raised the $\mathrm{C}$ content of the sediment to $11 \%$ but resulting $\mathrm{pH}$ was not reported. Sorption of organic pollutants to the char was determined by evaluating the genotoxicity to the earthworm Eisenia fetida. The charred rice crop residue, containing some black carbon, at low mixture rates $(1 \%, 3 \%$ and $5 \%)$ reduced genotoxic damage of the organic pollutants, however at a mixture rate of $10 \%$ the rice-char itself caused genotoxic damage to the earthworm [47].

Even though the chars used in these studies [46, 47] are both considered slash-and-burn residue, the materials are quite different as indicated by the high $\mathrm{C}$ content of the wood-derived char-soil mixture $(39 \% \mathrm{C})$ versus the low $\mathrm{C}$ of the rice-derived char-soil mixture $(11 \% \mathrm{C})$. Therefore, one could expect different responses due to the inherent differences in black carbon chemistries. The low $\mathrm{C}$ content of the rice char also indicates that this material was likely more ash, and probably had high residual mineral content as well. Application rate was another substantial difference between the studies. Regardless, even though genotoxic damage occurred in one case, short-term survivorship was not affected by either slash-and-burn product. In comparing these studies, the type of char rather than any soil or resultant $\mathrm{pH}$ effect probably contributed most to the observed outcome. This illustrates the current limitation in further comparisons, due to the lack of adequate characterization and documentation of the black carbon additions.

3.2. Synthetic Pyrolysis Char. Slow or fast pyrolysis in small batch reactors has allowed small scale synthetic production of biochars from feedstocks including hardwood, softwood, poultry litter, and tree nut shells at temperatures ranging as low as $400^{\circ} \mathrm{C}$ to as high as $600^{\circ} \mathrm{C}$ (Table 1 ). Laboratory and field testing of these biochars at rates of 5 to $180 \mathrm{Mgha}^{-1}$ have been conducted. In laboratory trials, standard preference/avoidance assays have been used whereby earthworms, typically E. fetida, are offered a choice between a soil containing no char and a soil containing biochar at increasing concentrations. Two of the three studies using this approach showed no preference to slightly greater preference for the biochar-soil mixtures over the nonamended soil $[48,49]$. In the third study [50] earthworms significantly avoided both a $10 \%$ and $20 \%$ apple wood chip biochar-soil mixture, until the biochar was prewetted (see below).

Toxicity of wood-derived and poultry litter-derived biochars were directly tested in 28-day or longer-term incubations. In a 28-day assay, Liesch et al. [12] examined the impact of two biochars (pine chip and poultry litter) on the mortality and growth of earthworms (E. fetida) in a simulated soil (70\% sand, 20\% kaolin, and 10\% sphagnum peat). The authors attributed mortality and reduced growth rates at the two highest biochar amendment rates, 68 and $90 \mathrm{Mgha}^{-1}$, to alterations in soil $\mathrm{pH}$. They also noted a quick mortality (within the first five days) with poultry litter biochar amended soils. The authors speculated that this could be due to the rapid $\mathrm{pH}$ alteration or ammonia concentration [12]. It is well established that earthworms are sensitive to $\mathrm{pH}[51,52]$. However, other causes of quick mortality in earthworm studies have been observed. For instance, Schmidt et al. [53] observed initial mortality (within the first 7-d) of earthworms during studies with dried maize residue, which they attributed to potential physical damage arising from the dry material sticking to the earthworm's body. More recently, Li et al. [50] discovered that once biochar was premoistened, the initial avoidance of the biochar by earthworms was overcome. Similarly, once the corn stover residue was premoistened, initial mortality disappeared [53]. Since the moisture status of biochars could be different due to different chemical and physical properties $[23,39,54]$ as well as storage conditions, the alteration of earthworm behavior by dry biochar additions is a probable cause of short-term negative impacts observed in earthworm-biochar incubations, as noted by Li et al. [50].

Li et al. [50] evaluated biochar toxicity in a 28-day lab incubation and found that the biochar at $10 \%$ and $20 \%$ mixtures significantly increased weight loss over controls, but did not affect reproduction. Polyaromatic hydrocarbons (PAHs) were detected in the biochar at concentrations below environmental concern, but no evidence of oxidative stress, indicating uptake of these potentially toxic compounds, occurred [50]. Gomez-Eyles et al. [55] also conducted 28day and 56-day toxicity studies but the scope of the study was designed to evaluate the deciduous hardwood-derived biochar as a bioremediation tool. The biochar was mixed into a contaminated soil collected from a gas works site at $10 \%$. Although no earthworms died, they did lose weight, and after 56-d did uptake PAHs and heavy metals from the contaminated soil; however, in the presence of biochar they were found to have a reduced accumulation of contaminants in their body tissue [55]. Notably, however, Gomez-Eyles et al. [55] attributed the observed weight loss primarily to the presence of biochar. However, it was uncertain if reduced feeding activity of contaminated soil in the presence of biochar (see Section 4) was responsible for the reduced body accumulation of contaminants.

3.3. Wood Ash. There have been mixed observations of earthworm dynamics following wood ash additions, but many studies reported reductions in population numbers (Table 1). Haimi et al. [56] noted a virtual immediate decrease (within 20-d) in earthworm numbers when wood ash was added to soil, but difference in the microarthropod population took 4 months to develop, with total numbers of microarthropds being decreased at the highest two 
amendment levels (2500 and $5000 \mathrm{~kg} \mathrm{ha}^{-1}$ ). However, the general conclusion was that wood ash above $2500 \mathrm{~kg} \mathrm{ha}^{-1}$ decreased earthworm population densities. This is interesting since the overall impact on microbial populations (microbial biomass $\mathrm{C}$ or fungal ergosterol) was insignificant among the wood ash additions from this same study [57]. The total biomass of enchytraeid worms was also reduced by wood ash application when it was mixed with the soil $\left(5000 \mathrm{~kg} \mathrm{ha}^{-1}\right)$ [58]. In further studies, the negative impact on Cognettia sphagnetorum (Enchytraeidae) populations was confirmed when wood ash was added solely to acidic forest soils [59]. Cox et al. [60] observed that there was no significant difference on total mass or abundance of earthworms in coal ash amended soils, despite the alkaline nature of the amendment.

However, these decreases in enchytraeid populations from wood ash additions can be overcome. If the wood ash was left on the soil surface and not incorporated, no significant impact on enchytraeid numbers was observed [58]. Nieminen [61] observed that the negative impacts of wood ash additions on the enchytraeid populations could be overcome through labile carbon additions. Population numbers were also noted to increase 2 yrs after an ash application occurred [62].

3.4. Historical Impacts and Other Field Studies. Earthworm populations are prevalent in many soil systems where charcoal from natural fires or controlled burns occurs. Populations of native Diplocardia spp. (Megascolecidae) occur in the subtropical southern half the United States $[63,64]$. These megascolecids, including Diplocardia mississippiensis, influence nutrient cycling in fire-controlled pinelands [65, 66]. Populations of European lumbricids along with native megascolecids are found in fire-affected Southern California chapparal soils $[67,68]$, where they also are important to nutrient availability [69]. In tropical regions, populations of the peregrine earthworm species, P. corethrurus, are capable of translocating charcoal residues from slash-and-burn land clearings deeper into the soil profile [70]. This activity by $P$. corethrurus indicates its potentially vital role in stabilizing organic matter and historical development of Terra preta soils $[46,71]$. Because of their vital role, some researchers have proposed that earthworms, particularly in the tropics, can be used as ecosystem engineering tools to maintain and/or improve soil fertility and ecosystem function [72] particularly in conjunction with charcoal additions [73].

Limited studies were available reporting earthworm populations in agricultural systems receiving biochar-like substances or biochar; these studies included [74, 75]. Topoliantz et al. [74] observed a difference in earthworm abundance for combined charcoal + other organic amendments, compared to a natural fallow field. However, in this study they observed no statistically significant differences at harvest time in the distribution of cocoons and adults. The authors did not compare the results to an equivalently tilled field, nor did they evaluate the impact of a charcoal-only amendment, which complicates the comparisons. For the total numbers, all tilled treatments reduced the numbers of earthworms, which is known to occur in other studies on the impact of tillage [76]. Husk and Major [75] provide a nonpeer reviewed report on earthworm populations sampled by handsorting and mustard application over a two-year nonreplicated study on field application of a wood-derived biochar. Their first sampling was taken two months after biochar application at a rate of $5.6 \mathrm{Mgha}^{-1}$. Earthworm populations in six out of eight sample dates were generally greater in the biochar plot than the control plot, however, standard error bars from within-plot replicates generally overlapped, suggesting lack of significant statistical differences between biochar and control plots.

3.4.1. Rosemount Biochar Field Plots. Earthworm abundance was evaluated in a subset of experimental biochar plots at the University of Minnesota Research and Outreach Center in Rosemount, MN USA $\left(44^{\circ} \mathrm{N}, 93^{\circ} \mathrm{W}\right)$. These plots are part of the USDA-ARS multilocation biochar and pyrolysis research effort (Spokas, unpublished). Eight treatments were established using a completely randomized design with three replications: (i) control (no amendment), (ii) composted manure, (iii) fast pyrolysis hardwood biochar, (iv) fast pyrolysis hardwood biochar + manure, (v) fast pyrolysis macadamia nut biochar, (vi) slow pyrolysis wood pellet biochar, (vii) slow pyrolysis wood waste biochar, and (viii) a slow pyrolysis hardwood biochar. Each individual plot measures $4.88 \mathrm{~m}$ on a side $\left(16^{\prime} \times 16^{\prime}\right)$ with a $3-\mathrm{m}\left(10^{\prime}\right)$ buffer zone between plots. The biochar was applied at a rate of $22.5 \mathrm{Mg} \mathrm{ha}^{-1}$ and incorporated by rotary tillage $(15 \mathrm{~cm}$ depth) in the fall of 2008 .

Earthworm assessments were made in the spring of 2011 after two full years of continuous no-till corn. Sampling within a circular $0.25 \mathrm{~m}^{2}$ area in each of five treatments was aided by an electrical field sampling device [77]. Briefly, three step-increases in field strength with corresponding alterations in the electrical field orientation by an octet arrangement of electrical poles were conducted over a 20 minute sampling period. A two- or three-pole electrical field was held for approximately two minutes with the increase in the field strength made after a complete circuit was accomplished. Earthworms were removed once fully exposed at the soil surface and placed in a bucket for quantification. Earthworms were classed as pigmented or nonpigmented then sorted into three size categories and counted. Size categories were roughly equivalent to hatchlings, juveniles and near-clitellate adults within pigmentation class, and actual lengths do not specifically overlap. One plot was manually excavated within the circle influenced by the electrical sampling device and hand-sorted; a total of $82 \%$ of the earthworms were retrieved by the electrical device in this plot, additional confirmation checks were not performed. Only one near-clitellate adult earthworm, Aporrectodea sp. possibly A. rosea, was sampled in the fast pyrolysis + manure treatment (treatment iv), no clitellated or other near-clitellate earthworms were observed. Due to the field logistic issues and the sampling time required per plot, no replicates were achieved. However, based on this limited data there were no drastic impacts on total earthworm 
abundance as a function of the different biochar types after two years in field production (Figure 1). The reduced abundance in the composted manure treatment was of unknown cause, but probably related to spatial heterogeneity of earthworm populations, since all plots were fertilized equivalently (accounting for initial manure- $\mathrm{N}$ in year 1 only).

The field studies indicate that biochar, charcoal, or occurrence of fire does not significantly affect long-term field populations of earthworms. In the studies evaluated however, short-term impacts, those which may occur within the first several days to weeks after burning or application, are unknown, with one noted exception: successful harvesting of Diplocardia spp. for the fishing industry (bait) is known to take place primarily in recently (within days) control-burned forest areas in the Appalachicola National Forest, Florida, USA [64]. Topoliantz and Ponge [45, 46] have already shown that $P$. corethrurus was unaffected by biochar in short-term studies, but field application rates were difficult to discern. As with Husk and Major [75] a low application rate of biochar, particularly one derived from wood, might not have had a substantial effect in the field. However, probable shortterm effects with higher biochar application rates could not be substantiated by the Rosemount field trial because population assessment occurred two years after application.

\section{Biochar Effects on Earthworm Activity}

Some details on earthworm activity, including burrowing, feeding and casting, were available in the studies evaluated. Effects on earthworm mating activity, assessed via cocoon production, were noted earlier. Observations on earthworm casts and gut materials indicate that charcoal fragments are ingested by earthworms $[45,46,71,78]$. Topoliantz and Ponge [45] utilized 2-D microcosms to study P. corethrurus activity in soil and charcoal amended soil. Two soils were placed in a plexiglass frame, which enabled viewing of earthworm burrowing and casting activity. Ten replicates were run and they observed a few significant differences. The first was a drastic difference in the burrowing activity, with $14.6 \mathrm{~cm}^{3}$ of burrows created in the soil only side and a total burrow volume of $1.7 \mathrm{~cm}^{3}$ on the soil + charcoal side [45]. This data suggests that $P$. corethrurus did not prefer the environment in the soil + charcoal side. Furthermore, there were significant differences in the volume of casts, with $5.5 \mathrm{~cm}^{3}$ in the soil alone and $0.3 \mathrm{~cm}^{3}$ in the charcoal + soil side. Even though the cast density was lower, the earthworm still ingested and created some casts with charcoal. Furthermore, and perhaps most important, there was an absence of feeding burrows observed in soil + charcoal side, with all feeding burrows present solely in the control soil. This observation, coupled with the differences in the cast production, would suggest that this particular charcoal was not being utilized by the earthworms as a food source [45] and suggested that the earthworms were pushing the charcoal bits aside rather than ingesting them.

Even though charcoal has been found in earthworm gut material, ingestion does not necessarily indicate utilization as an energy source. Ingestion of a basic $\mathrm{pH}$ charcoal would modify earthworm internal gut $\mathrm{pH}$, which could assist in the assimilation of other resources. Notably, this has been the presumed function of earthworm calciferous glands [79]. The application rate of nearly $60 \%$ charcoal could be the reason Topoliantz and Ponge [45] observed less feeding activity in the char-soil mixture whereas lower more applicable field rates might not have had the same impact. However, other laboratory studies that used lower application rates did not indicate that charcoal was a food source for earthworms, but in fact, inhibited feeding activity and induced earthworm weight loss (Table 1) $[12,50,55]$. Microbes are hypothesized to colonize charcoal [80] and may be protected within the charcoal pores. Therefore, less food might be available to the earthworms [45]. This phenomenon could also explain the lack of feeding burrows observed within the charcoal amended soil in the Topoliantz and Ponge [45] study. These observations could be true for particular soil-biochar combinations but might not be universally the case, particularly in light of the differing responses observed for different biochars and soil combinations [12, 48]. Regardless of any nutritive value, the ingestion of charcoal particles by earthworms and resulting bioturbation and transport of these particles into the soil profile is an important force in the maintenance and improvement of soil function, as discussed earlier.

\section{Biochars, Soils, and Earthworm Interactions}

Biochar and soil type have an influence on the response of earthworms following biochar additions (Table 1). Data from Van Zweiten et al. [48] indicates that earthworm preference is a function of both biochar and soil type. They observed the preferences of E. fetida in combination with two different biochars (two different mixture ratios of paper mill sludge and waste wood chips) in two different soil types [a ferrosol (productive red Australian agricultural soil) and a calcarosol (calcareous/calcite rich soil; lower productivity) [81]]. E. fetida preferred the biochar amended ferrosol soil compared to the unamended ferrosol soil, whereas no significant difference in earthworm preference was observed for biochar amended calcarosol soil. One aspect that stands out in this study is that the biochar addition to the ferrosol increased soil $\mathrm{pH}$ from 4.2 to 5.9 , but addition to the calcarosol did not change $\mathrm{pH}$ from 7.6 (Table 1). Also notable, the biochar which had a greater proportion of waste wood to paper sludge (70:30 mix) was also preferred by the earthworms. In our own studies [12], survivorship of $E$. fetida on pine chip-derived biochar was higher than poultry litter-derived biochar.

Noguera et al. [13] assessed the effect of two different biochars with $P$. corethrurus on growth dynamics of rice plants in two different soils in a laboratory study. One was a eucalyptus-derived biochar made at a temperature of $350^{\circ} \mathrm{C}$ and applied at a rate of $2.5 \%$ to a nutrient rich Inceptisol, the second was a household-use charcoal tested at a rate of $4.5 \%$ in a nutrient poor oxisol with and without added fertility. Effects on earthworm survivorship, growth, or behavior were not reported. In mixtures of worms + biochar more plant growth was observed in the nutrient rich soil than with 
biochar or earthworms alone, however, an earthworm-only effect but no biochar or worm + biochar influence was found in the nutrient poor soil [13]. In a second study with only the eucalyptus-derived biochar, Noguera et al. [82], determined that there was a variable response in growth due to differences among rice cultivars when biochar and earthworms were added to the nutrient rich Inceptisol.

Beesley and Dickenson [14] applied a biochar made from hardwoods at $400^{\circ} \mathrm{C}$ in steel ring furnaces at $30 \%$ (volume basis) to an urban soil with a sand: silt: clay content of $83: 16: 1$ and a $7.9 \mathrm{pH}$. They added fifteen juvenile Lumbricus terrestris to the mesocosms, but direct effects on the earthworms were not reported. The biochar caused a significant increase in pore water concentrations of $\mathrm{As}, \mathrm{Cu}$, and $\mathrm{Pb}$ within the year of testing. However, when earthworms were present, the concentrations of $\mathrm{As}$ and $\mathrm{Cu}$ in the leachate collected from biochar amended soils were decreased. The authors attributed this decrease to the effect earthworms had on reducing the concentration of dissolved organic $\mathrm{C}$ (DOC) as well as the amount of pore water moving through the soil chambers. Beesley and Dickenson [14] hypothesized that an increased $\mathrm{pH}$ (6.6 of the soil to 9.9) caused by the addition of biochar might have positively influenced the earthworms and their subsequent effects on DOC. However, they did not assess the potential for $L$. terrestris to construct and line burrows with organic matter shown to reduce leaching of organic pesticides [83]. These statements made by Beesley and Dickenson [14] support observations made earlier in this review that biochar application to soil will impact earthworm activity (see Section 4).

Despite the limited number of studies specifically examining different biochar types, the general conclusion is that there are different responses as a function of soil and biochar properties. From the existing studies, it still is not clear what particular mechanisms are responsible for these observations. However, Noguera et al. [13] determined that the interaction resulting in increased plant growth observed between biochar and earthworms was additive rather than synergistic. These data strongly suggest that soil characteristics, biochar characteristics, and plant characteristics will affect the response observed when biochar is added to soils with earthworm populations.

\section{Future Steps}

Field populations of earthworms occurring in fire-affected systems indicate that adaptation to the presence of natural charcoal is possible. But yet unknown is if the input of natural or synthetic biochar has or had any initial impact on the preexisting earthworm populations. Overall from this data, there is the suggestion that the short-term impacts on earthworms are either nonsignificant or negative. As indicated by our field study, earthworm populations in biochar amended plots were similar to the control plots after 2 years of continuous no-till corn production in Minnesota. Other field observations were likely made after the population was able to rebound. This interval would include the two-month interval between application and sampling as in Husk and Major [75]. Field studies using small amounts of biochar $\left(<10 \mathrm{Mg} \mathrm{ha}^{-1}\right)$ potentially avoid negative short-term impacts. Field studies are needed which evaluate a greater range of application rates; preferably they would be paired with laboratory preference/avoidance assays to establish appropriate ranges of application rates. Assessment of earthworm populations are needed prior to, immediately at, and over the long term after biochar application to the soil.

In the evaluations reviewed, biochar was never clearly used as a food substrate. Although we cannot discount the potential use of biochar for digestive purposes by field populations, laboratory studies certainly showed that earthworm behaviors were altered, and soil ingestion was reduced. A few of these laboratory studies demonstrated that some biochars are likely to be potential toxins [47] but lethal results likely depend on amendment rates [12]. Beesley and Dickenson [14] did show that leaching of potential toxins, including $\mathrm{Pb}, \mathrm{As}$, and $\mathrm{Cu}$, was increased with biochar application, though the biochar might not have been the direct source of these elements. Regardless, this observation runs counter to the suggested use of biochars to sorb environmental toxins $[47,55]$. With earthworms active in the soil, however, reduced concentrations of potential toxins in pore water were found [14]. Thus the natural movement of biochars into the soil through earthworm activity, as shown by Topoliantz and Ponge [45, 46], might assist the use of biochar as a bioremediation tool in contaminated soils. Studies which address earthworm activity, in particular burrowing, ingestion, and casting, which might affect movement of biochar in and around the soil environment, would be useful in determining more specific interactions with soil function. Studies examining activity will also need to account for the ecological strategy the earthworm species present could be categorized into, particularly as these strategies define where and how within the soil profile they feed and burrow and the resulting affects on the soil environment [84]. Another aspect needing to be addressed is potential effects on earthworm migration. The reader is referred to Butt and Grigoropoulou [85] for information on how to properly address analysis of earthworm populations.

The complications of evaluating biochar research stem from the deficiency of many of these studies to report on elemental content, ash content, $\mathrm{pH}$, soils used, feedstock material, and method of production. Though wood-derived biochars used in the studies described here had more null effects, and other biochars from mixes with sludges, manures, or crop residues had negative effects, the data also indicate $\mathrm{pH}$ changes in the assessment medium, whether that is field soil or simulated soil, might influence the outcome. The null to positive impacts of wood-based biochars on agronomic yields has also been observed in biochar field studies $[86,87]$. There is an identified need to standardize earthworm studies [88], and adequate data must be presented on the biochar properties, the environment in which they are to be used and influence on soil biota, so future meta-analyses can be conducted. More detailed initial and final evaluations of earthworm populations in short as well as long-term studies are necessary to elucidate the immediate 
and lasting effects of biochar before it becomes a widespread soil amendment.

\section{References}

[1] W. R. Wood and D. L. Johnson, "A survey of disturbance processes in archaeological site formation," Advances in Archaeological Method and Theory, vol. 1, pp. 315-381, 1978.

[2] C. Darwin, The Formation of Vegetable Mould, through the Actions of Worms, with Observations on Their Habits, John Murray, London, UK, 1881.

[3] P. Lavelle, D. Bignell, M. Lepage et al., "Soil function in a changing world: the role of invertebrate ecosystem engineers," European Journal of Soil Biology, vol. 33, no. 4, pp. 159-193, 1997.

[4] J. Lehmann, M. Rillig, J. Thies, C. A. Masiello, W. C. Hockaday, and D. Crowley, "Biochar effects on soil biota-a review," Soil Biology and Biochemistry, vol. 43, no. 9, pp. 1812-1836, 2011.

[5] R. Lal, "World cropland soils as a source or sink for atmospheric carbon," Advances in Agronomy, vol. 71, pp. 145191, 2001.

[6] M. K. Jarecki and R. Lal, "Crop management for soil carbon sequestration," Critical Reviews in Plant Sciences, vol. 22, no. 6, pp. 471-502, 2003.

[7] L. E. Drinkwater and S. S. Snapp, "Nutrients in agroecosystems: rethinking the management paradigm," Advances in Agronomy, vol. 92, pp. 163-186, 2007.

[8] R. Lal, "Challenges and opportunities in soil organic matter research," European Journal of Soil Science, vol. 60, no. 2, pp. 158-169, 2009.

[9] G. G. Brown, C. A. Edwards, and L. Brussaard, "How earthworms effect plant growth: burrowing into the mechanisms," in Earthworm Ecology, C. A. Edwards, Ed., pp. 13-49, CRC Press, Boca Raton, Fla, USA, 2nd edition, 2004.

[10] S. L. Lachnicht, R. W. Parmelee, D. McCartney, and M. Allen, "Characteristics of macroporosity in a reduced tillage agroecosystem with manipulated earthworm populations: Implications for infiltration and nutrient transport," Soil Biology and Biochemistry, vol. 29, no. 3-4, pp. 493-498, 1997.

[11] J. Domínguez, P. J. Bohlen, and R. W. Parmelee, "Earthworms increase nitrogen leaching to greater soil depths in row crop agroecosystems," Ecosystems, vol. 7, no. 6, pp. 672-685, 2004.

[12] A. M. Liesch, S. L. Weyers, J. W. Gaskin, and K. C. Das, "Impact of two different biochars on earthworm growth and survival," Annals of Environmental Science, vol. 4, pp. 1-9, 2010.

[13] D. Noguera, M. Rondón, K. R. Laossi et al., "Contrasted effect of biochar and earthworms on rice growth and resource allocation in different soils," Soil Biology and Biochemistry, vol. 42, no. 7, pp. 1017-1027, 2010.

[14] L. Beesley and N. Dickinson, "Carbon and trace element fluxes in the pore water of an urban soil following greenwaste compost, woody and biochar amendments, inoculated with the earthworm Lumbricus terrestris," Soil Biology and Biochemistry, vol. 43, no. 1, pp. 188-196, 2011.

[15] T. P. Jones, W. G. Chaloner, and T. A. G. Kuhlbusch, Proposed Biogeological and Chemical Based Terminology for Fire-Altered Plant Matter, Springer, Berlin, Germany, 1997.

[16] E. D. Goldberg, Black Carbon in the Environment: Properties and Distribution, John Wiley \& Sons, New York, NY, USA, 1985.

[17] J. Lehmann, "Bio-energy in the black," Frontiers in Ecology and the Environment, vol. 5, no. 7, pp. 381-387, 2007.
[18] K. A. Spokas, "Review of the stability of biochar in soils: predictability of O:C molar ratios," Carbon Management, vol. 1, no. 2, pp. 289-303, 2010.

[19] IBI, International Biochar Initiative. Biochar Product DefIBI, International Biochar Initiative. Biochar Product Definition and Standard Draft Version, 2011, http://www.biocharinternational.org/sites/default/files/Biochar\%20Product $\% 20$ Defintion\%20and\%20Standard\%20DRAFT\%20VERSION\% 20WG\%20round\%202.pdf.

[20] D. A. Laird, P. Fleming, D. D. Davis, R. Horton, B. Wang, and D. L. Karlen, "Impact of biochar amendments on the quality of a typical Midwestern agricultural soil," Geoderma, vol. 158, no. 3-4, pp. 443-449, 2010.

[21] J. M. Novak, W. J. Busscher, D. L. Laird, M. Ahmedna, D. W. Watts, and M. A. S. Niandou, "Impact of biochar amendment on fertility of a southeastern coastal plain soil," Soil Science, vol. 174, no. 2, pp. 105-112, 2009.

[22] L. Van Zwieten, S. Kimber, S. Morris et al., "Effects of biochar from slow pyrolysis of papermill waste on agronomic performance and soil fertility," Plant and Soil, vol. 327, no. 1, pp. 235-246, 2010.

[23] C. E. Brewer, R. Unger, K. Schmidt-Rohr, and R. C. Brown, "Criteria to select biochars for field studies based on biochar chemical properties," Bioenergy Research. In press.

[24] K. A. Spokas, W. C. Koskinen, J. M. Baker, and D. C. Reicosky, "Impacts of woodchip biochar additions on greenhouse gas production and sorption/degradation of two herbicides in a Minnesota soil," Chemosphere, vol. 77, no. 4, pp. 574-581, 2009.

[25] K. Spokas and D. Reicosky, "Impacts of sixteen different biochars on soil greenhouse gas production," Annals of Environmental Science, vol. 3, pp. 179-193, 2009.

[26] J. L. Smith, H. P. Collins, and V. L. Bailey, "The effect of young biochar on soil respiration," Soil Biology and Biochemistry, vol. 42, no. 12, pp. 2345-2347, 2010.

[27] L. van Zwieten, S. Kimber, S. Morris et al., "Influence of biochars on flux of $\mathrm{N}_{2} \mathrm{O}$ and $\mathrm{CO}_{2}$ from Ferrosol," Australian Journal of Soil Research, vol. 48, no. 6-7, pp. 555-568, 2010.

[28] A. Zhang, L. Cui, G. Pan et al., "Effect of biochar amendment on yield and methane and nitrous oxide emissions from a rice paddy from Tai Lake plain, China," Agriculture, Ecosystems and Environment, vol. 139, no. 4, pp. 469-475, 2010.

[29] C. Scheer, P. Grace, D. Rowlings, S. Kimber, and L. Van Zwieten, "Effect of biochar amendment on the soil-atmosphere exchange of greenhouse gases from an intensive subtropical pasture in northern New South Wales, Australia," Plant and Soil, vol. 345, no. 1, pp. 47-58, 2011.

[30] A. R. Zimmerman, "Abiotic and microbial oxidation of laboratory-produced black carbon (biochar)," Environmental Science and Technology, vol. 44, no. 4, pp. 1295-1301, 2010.

[31] B. A. McCarl, C. Peacocke, R. Chrisman, C. Kung, and R. D. Sands, "Economics of biochar production, utilization and greenhouse gas offsets," in Biochar for Environmental Management, J. Lehmann and S. Joseph, Eds., pp. 341-357, Earthscan, London, UK, 2009.

[32] D. Granatstein, C. E. Kruger, H. Collins, S. Galinato, M. Garcia-Perez, and J. Yoder, "Use of biochar from the pyrolysis of waste organic material as a soil amendment," Final Project Report, Center for Sustaining Agriculture and Natural Resources, Washington State University, Wenatchee, Wash, USA, 2009.

[33] K. G. Roberts, B. A. Gloy, S. Joseph, N. R. Scott, and J. Lehmann, "Life cycle assessment of biochar systems: Estimating the energetic, economic, and climate change potential," 
Environmental Science and Technology, vol. 44, no. 2, pp. 827833, 2010.

[34] S. P. Galinato, J. K. Yoder, and D. Granatstein, The Economic Value of Biochar in Crop Production and Carbon Sequestration, School of Economic Sciences, Washington State University, Pullman, Wash, USA, 2010.

[35] M. M. Williams and J. C. Arnott, "A comparison of variable economic costs associated with two proposed biochar application methods," Annals of Environmental Science, vol. 4, pp. 23-30, 2010.

[36] J. Lehmann and S. Joseph, Biochar for Environmental Management Science and Technology, Earthscan, London, UK, 2009.

[37] Y. X. Liu, W. Liu, W. X. Wu, Z. K. Zhong, and Y. X. Chen, "Environmental behavior and effect of biomass-derived black carbon in soil: a review," Chinese Journal of Applied Ecology, vol. 20, no. 4, pp. 977-982, 2009.

[38] C. Atkinson, J. Fitzgerald, and N. Hipps, "Potential mechanisms for achieving agricultural benefits from biochar application to temperate soils: a review," Plant and Soil, vol. 337, no. 1, pp. 1-18, 2010.

[39] S. P. Sohi, E. Krull, E. Lopez-Capel, and R. Bol, "A review of biochar and its use and function in soil," Advances in Agronomy, vol. 105, pp. 47-82, 2010.

[40] J. M. Novak and W. J. Busscher, "Selection and use of designer biochars to improve characteristics of southeastern USA costal plain degraded soils," in Advanced Biofuels and by Products, J. W. Lee, Ed., Springer Science, 2011.

[41] L. Etiégni and A. G. Campbell, "Physical and chemical characteristics of wood ash," Bioresource Technology, vol. 37, no. 2, pp. 173-178, 1991.

[42] R. M. Pitman, "Wood ash use in forestry-a review of the environmental impacts," Forestry, vol. 79, no. 5, pp. 563-588, 2006.

[43] J. R. Pels and A. J. Sarabèr, "Utilization of biomass ashes," in Solid Biofuels for Energy, P. Grammelis, Ed., pp. 219-235, Springer, London, UK, 2011.

[44] B. Glaser, J. Lehmann, and W. Zech, "Ameliorating physical and chemical properties of highly weathered soils in the tropics with charcoal-a review," Biology and Fertility of Soils, vol. 35, no. 4, pp. 219-230, 2002.

[45] S. Topoliantz and J. F. Ponge, "Burrowing activity of the geophagous earthworm Pontoscolex corethrurus (Oligochaeta: Glossoscolecidae) in the presence of charcoal," Applied Soil Ecology, vol. 23, no. 3, pp. 267-271, 2003.

[46] S. Topoliantz and J. F. Ponge, "Charcoal consumption and casting activity by Pontoscolex corethrurus (Glossoscolecidae)," Applied Soil Ecology, vol. 28, no. 3, pp. 217-224, 2005.

[47] X. Cui, H. Wang, L. Lou et al., "Sorption and genotoxicity of sediment-associated pentachlorophenol and pyrene influenced by crop residue ash," Journal of Soils and Sediments, vol. 9, no. 6, pp. 604-612, 2009.

[48] L. Van Zwieten, S. Kimber, S. Morris et al., "Effects of biochar from slow pyrolysis of papermill waste on agronomic performance and soil fertility," Plant and Soil, vol. 327, no. 1, pp. 235-246, 2010.

[49] K. Y. Chan, L. Van Zwieten, I. Meszaros, A. Downie, and S. Joseph, "Using poultry litter biochars as soil amendments," Australian Journal of Soil Research, vol. 46, no. 5, pp. 437-444, 2008.

[50] D. Li, W. C. Hockaday, C. A. Masiello, and P. J. J. Alvarez, "Earthworm avoidance of biochar can be mitigated by wetting," Soil Biology and Biochemistry, vol. 43, no. 8, pp. 17321737, 2011.
[51] S. M. Saleh, R. F. Harris, and O. N. Allen, "Fate of Bacillus thuringiensis in soil: effect of soil $\mathrm{pH}$ and organic amendment," Canadian Journal of Microbiology, vol. 16, no. 8, pp. 677-680, 1970.

[52] M. S. Laverack, "Tactile and chemical perception in earthworms-II responses to acid $\mathrm{pH}$ solutions," Comparative Biochemistry And Physiology, vol. 2, no. 1, pp. 22-34, 1961.

[53] O. Schmidt, C. M. Scrimgeour, and J. P. Curry, "Carbon and nitrogen stable isotope ratios in body tissue mucus of feeding and fasting earthworms (Lumbricus festivus)," Oecologia, vol. 118, no. 1, pp. 9-15, 1999.

[54] C. E. Brewer, K. Schmidt-Rohr, J. A. Satrio, and R. C. Brown, "Characterization of biochar from fast pyrolysis and gasification systems," Environmental Progress and Sustainable Energy, vol. 28, no. 3, pp. 386-396, 2009.

[55] J. L. Gomez-Eyles, T. Sizmur, C. D. Collins, and M. E. Hodson, "Effects of biochar and the earthworm Eisenia fetida on the bioavailability of polycyclic aromatic hydrocarbons and potentially toxic elements," Environmental Pollution, vol. 159, no. 2, pp. 616-622, 2011.

[56] J. Haimi, H. Fritze, and P. Moilanen, "Responses of soil decomposer animals to wood-ash fertilisation and burning in a coniferous forest stand," Forest Ecology and Management, vol. 129, no. 1-3, pp. 53-61, 2000.

[57] H. Fritze, A. Smolander, T. Levula, V. Kitunen, and E. Mälkönen, "Wood-ash fertilization and fire treatments in a Scots pine forest stand: effects on the organic layer, microbial biomass, and microbial activity," Biology and Fertility of Soils, vol. 17, no. 1, pp. 57-63, 1994.

[58] M. Liiri, K. Ilmarinen, and H. Setälä, "The significance of Cognettia sphagnetorum (Enchytraeidae) on nitrogen availability and plant growth in wood ash-treated humus soil," Plant and Soil, vol. 246, no. 1, pp. 31-39, 2002.

[59] M. Liiri, K. Ilmarinen, and H. Setälä, "Variable impacts of enchytraeid worms and ectomycorrhizal fungi on plant growth in raw humus soil treated with wood ash," Applied Soil Ecology, vol. 35, no. 1, pp. 174-183, 2007.

[60] D. Cox, D. Bezdicek, and M. Fauci, "Effects of compost, coal ash, and straw amendments on restoring the quality of eroded Palouse soil," Biology and Fertility of Soils, vol. 33, no. 5, pp. 365-372, 2001.

[61] J. K. Nieminen, "Labile carbon alleviates wood ash effects on soil fauna," Soil Biology and Biochemistry, vol. 40, no. 11, pp. 2908-2910, 2008.

[62] H. Lundkvist, "Wood ash effects on enchytraeid and earthworm abundance and enchytraeid cadmium content," Scandinavian Journal of Forest Research, vol. 13, supplement 2, pp. 86-95, 1998.

[63] G. E. Gates, "More on the earthworm genus Diplocardia," Megadrilogica, vol. 3, no. 1, pp. 1-48, 1977.

[64] P. F. Hendrix, M. A. Callaham Jr., and L. Kirn, "Ecology of nearctic earthworms in the southern USA. II. Effects of bait harvesting on Diplocardia (Oligochaeta, Megascolecidae) populations in Apalachicola National Forest, North Florida," Megadrilogica, vol. 5, no. 7, pp. 73-76, 1994.

[65] M. A. Callaham and P. F. Hendrix, "Impact of earthworms (Diplocardia: Megascolecidae) on cycling and uptake of nitrogen in coastal plain forest soils from northwest Florida, USA," Applied Soil Ecology, vol. 9, no. 1-3, pp. 233-239, 1998.

[66] S. L. Lachnicht and P. F. Hendrix, "Interaction of the earthworm Diplocardia mississippiensis (Megascolecidae) with microbial and nutrient dynamics in a subtropical spodosol," Soil Biology and Biochemistry, vol. 33, no. 10, pp. 1411-1417, 2001. 
[67] R. C. Graham and H. B. Wood, "Morphologic development and clay redistribution in lysimeter soils under chaparral and pine," Soil Science Society of America Journal, vol. 55, no. 6, pp. 1638-1646, 1991.

[68] A. C. Peterson, P. F. Hendrix, C. Haydu, R. C. Graham, and S. A. Quideau, "Single-shrub influence on earthworms and soil macroarthropods in the southern California chaparral," Pedobiologia, vol. 45, no. 6, pp. 509-522, 2001.

[69] A. L. Ulery, R. C. Graham, O. A. Chadwick, and H. B. Wood, "Decade-scale changes of soil carbon, nitrogen and exchangeable cations under chaparral and pine," Geoderma, vol. 65, no. 1-2, pp. 121-134, 1995.

[70] S. Topoliantz, J. F. Ponge, and P. Lavelle, "Humus components and biogenic structures under tropical slash-and-burn agriculture," European Journal of Soil Science, vol. 57, no. 2, pp. 269-278, 2006.

[71] B. Glaser, E. Balashov, L. Haumaier, G. Guggenberger, and W. Zech, "Black carbon in density fractions of anthropogenic soils of the Brazilian Amazon region," Organic Geochemistry, vol. 31, no. 7-8, pp. 669-678, 2000.

[72] D. McKey, S. P. Rostain, J. Iriarte et al., "Pre-Columbian agricultural landscapes, ecosystem engineers, and self-organized patchiness in Amazonia," Proceedings of the National Academy of Sciences of the United States of America, vol. 107, no. 17, pp. 7823-7828, 2010.

[73] J. F. Ponge, S. Topoliantz, S. Ballof et al., "Ingestion of charcoal by the Amazonian earthworm Pontoscolex corethrurus: a potential for tropical soil fertility," Soil Biology and Biochemistry, vol. 38, no. 7, pp. 2008-2009, 2006.

[74] S. Topoliantz, J. F. Ponge, and S. Ballof, "Manioc peel and charcoal: a potential organic amendment for sustainable soil fertility in the tropics," Biology and Fertility of Soils, vol. 41, no. 1, pp. 15-21, 2005.

[75] B. Husk and J. Major, "Commercial scale agricultural biochar field trial in Québec, Canada over two years: effects of biochar on soil fertility, biology and crop productivity and quality," BlueLeaf Biochar Field Trial, 2010, http://www.blue-leaf.ca/main-en/files/BlueLeaf\%20Biochar\% 20Field\%20Trial\%2008-09\%20Report-1.pdf.

[76] J. Simonsen, J. Posner, M. Rosemeyer, and J. Baldock, "Endogeic and anecic earthworm abundance in six Midwestern cropping systems," Applied Soil Ecology, vol. 44, no. 2, pp. 147$155,2010$.

[77] S. L. Weyers, H. H. Schomberg, P. F. Hendrix, K. A. Spokas, and D. M. Endale, "Construction of an electrical device for sampling earthworm populations in the field," Applied Engineering in Agriculture, vol. 24, no. 3, pp. 391-397, 2008.

[78] E. Eckmeier, R. Gerlach, J. O. Skjemstad, O. Ehrmann, and M. W. I. Schmidt, "Minor changes in soil organic carbon and charcoal concentrations detected in a temperate deciduous forest a year after an experimental slash-and-burn," Biogeosciences, vol. 4, no. 3, pp. 377-383, 2007.

[79] F. Smith, "The calciferous glands of Lumbricidae and Diplocardia," Illinois Biological Monographs, vol. 9, pp. 7-54, 1924.

[80] D. Warnock, J. Lehmann, T. Kuyper, and M. Rillig, "Mycorrhizal responses to biochar in soil-concepts and mechanisms," Plant and Soil, vol. 300, no. 1-2, pp. 9-20, 2007.

[81] R. F. Isbell, The Australian Soil Classification, CSIRO Publishing, Melbourne, Australia, 1996.

[82] D. Noguera, K. R. Laossi, P. Lavelle et al., "Amplifying the benefits of agroecology by using the right cultivars," Ecological Applications, vol. 21, no. 7, pp. 2349-2356, 2011.

[83] W. M. Edwards, M. J. Shipitalo, S. J. Traina, C. A. Edwards, and L. B. Owens, "Role of Lumbricus terrestris (L.) burrows on quality of infiltrating water," Soil Biology and Biochemistry, vol. 24, no. 12, pp. 1555-1561, 1992.

[84] G. Brown, "How do earthworms affect microfloral and faunal community diversity?" Plant and Soil, vol. 170, no. 1, pp. 209231, 1995.

[85] K. R. Butt and N. Grigoropoulou, "Basic research tools for earthworm ecology," Applied and Environmental Soil Science, vol. 2010, Article ID 562816, 12 pages, 2010.

[86] S. M. Haefele, Y. Konboon, W. Wongboon et al., "Effects and fate of biochar from rice residues in rice-based systems," Field Crops Research, vol. 121, no. 3, pp. 430-440, 2011.

[87] K. A. Spokas, K. B. Cantrell, J. M. Novak et al., "Biochar: a synthesis of its agronomic impact beyond carbon sequestration," Journal of Environmental Quality. In press.

[88] H. C. Fründ, K. Butt, Y. Capowiez et al., "Using earthworms as model organisms in the laboratory: Recommendations for experimental implementations," Pedobiologia, vol. 53, no. 2, pp. 119-125, 2010.

[89] H. Lundkvist, "Effects of clear-cutting on the enchytraeids in a Scots pine forest soil in central Sweden," Journal of Applied Ecology, vol. 30, no. 3, pp. 873-885, 1983.

[90] V. Huhta, R. Hyvonen, A. Koskenniemi, P. Vilkamaa, P. Kaasalainen, and M. Sulander, "Response of soil fauna to fertilization and manipulation of $\mathrm{pH}$ in coniferous forests," Acta Forestalia Fennica, vol. 195, pp. 1-30, 1986.

[91] J. Nieminen, "Combined effects of loose wood ash and carbon on inorganic $\mathrm{N}$ and $\mathrm{P}$, key organisms, and the growth of Norway spruce seedlings and grasses in a pot experiment," Plant and Soil, vol. 317, no. 1-2, pp. 155-165, 2009.

[92] J. K. Nieminen and J. Haimi, "Body size and population dynamics of enchytraeids with different disturbance histories and nutrient dynamics," Basic and Applied Ecology, vol. 11, no. 7, pp. 638-644, 2010. 

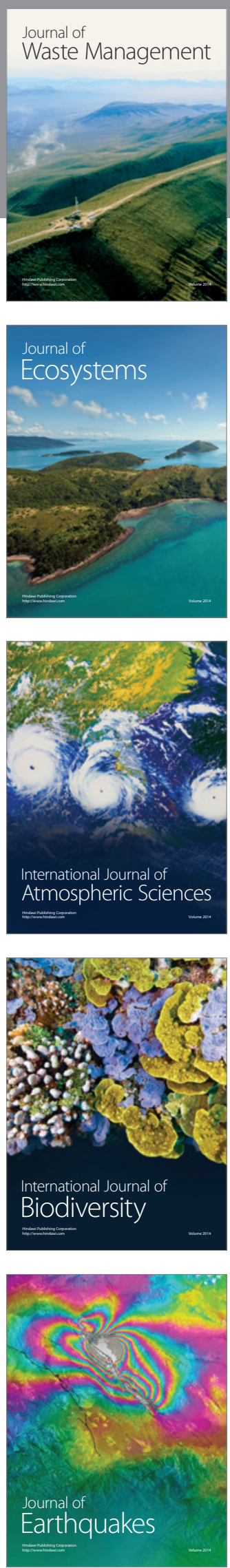
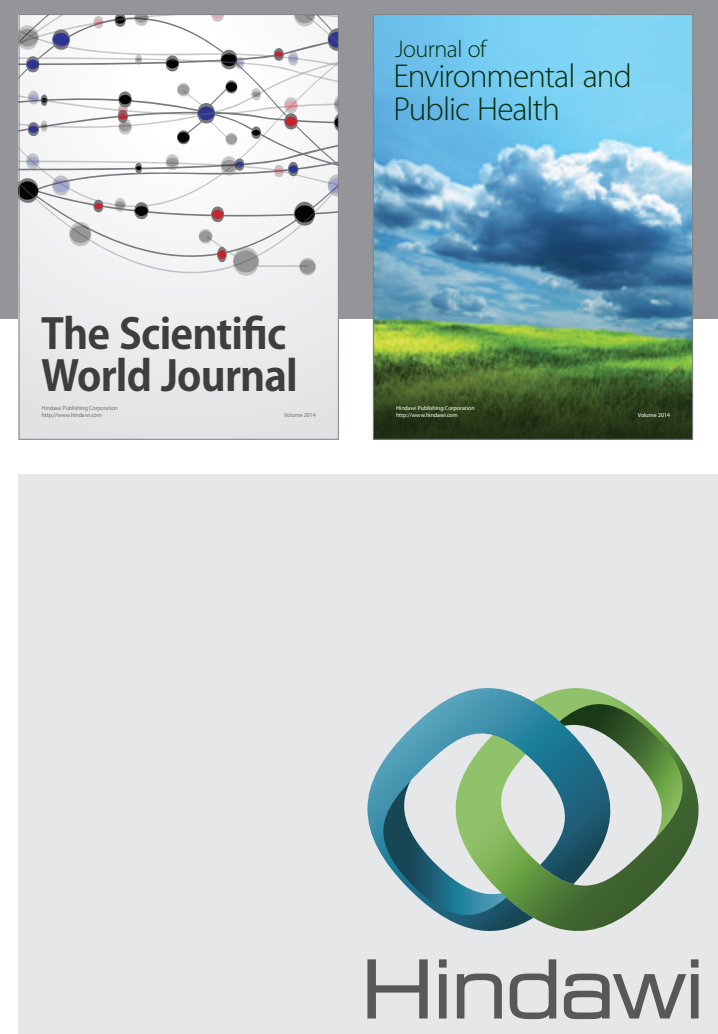

Submit your manuscripts at

http://www.hindawi.com
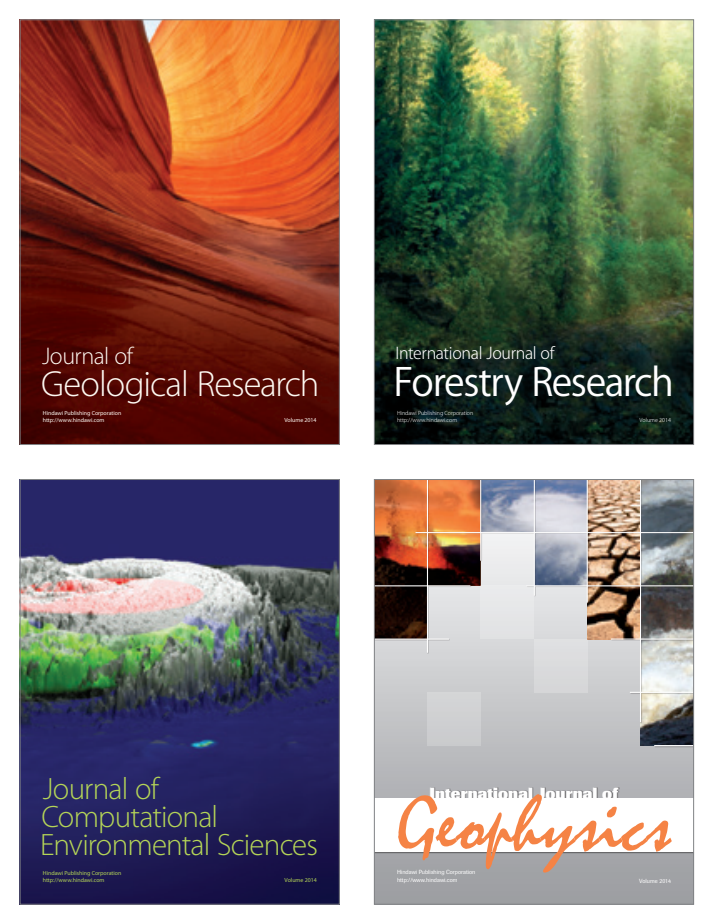
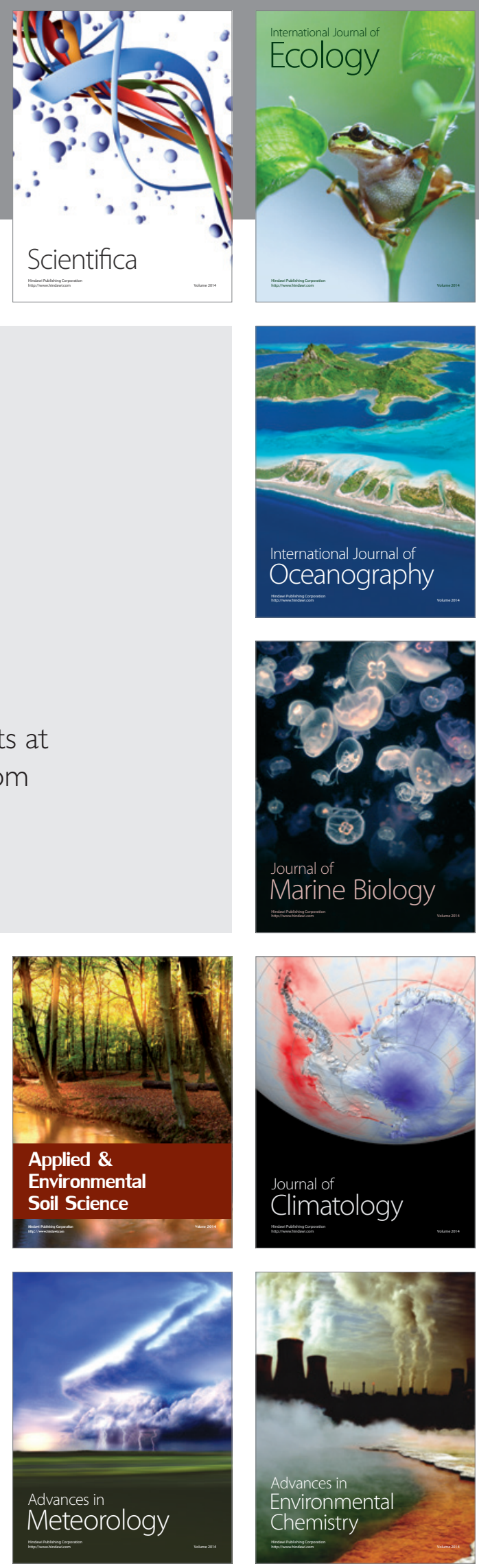